\title{
IZVRŠENJE U FRANCUSKOM UPRAVNOM SPORU
}

Izv. prof. dr. sc. Bosiljka Britvić Vetma*

Dr. sc. Ivan Malenica**
UDK: $35.077 .2(44)$

$342.924(44)$

DOI: 10.3935/zpfz.70.6.01

Pregledni znanstveni rad

Primljeno: listopad 2020.

U ovom radu najprije se upućuje na važnost analize izvršenja upravnosudskih odluka u francuskom upravnom pravu. To se čini analizom relevantnih propisa, primarno Zakonika o upravnom sudovanju, ali i uz pomoć mjerodavne sudske prakse. Ističe se bitna uloga dviju institucija (Odjela za izvješće i studije Državnog savjeta i Pučkog pravobranitelja), koje su dale velik doprinos efikasnom izvršenju upravnosudskih odluka u Republici Francuskoj. Nadalje se u radu prikazuju procesne metode koje se koriste u slučaju neizvršenja upravnosudskih odluka (poticajne mjere, prinudne mjere i represivne mjere). Ujedno se razmatra i odgovornost javnih službenika za neizvršenje upravnosudskih odluka te institut odgode izvršsenja. Konačno, zaključuje se kako se propisivanjem čitavog niza procesnih mjera u slučaju neizvršenja sudskih odluka dolazi do učinkovitog koncepta izvršenja.

Ključne riječi: izvršenje upravnosudskih odluka, upravni spor, Državni savjet, Pučki pravobranitelj, Zakonik o upravnom sudovanju

* Dr. sc. Bosiljka Britvić Vetma, izvanredna profesorica Pravnog fakulteta Sveučilišta u Splitu, Domovinskog rata 8, 21000 Split; bosiljka.britvic@pravst.hr;

ORCID ID: orcid.org/0000-0002-3393-5895

** Dr. sc. Ivan Malenica, ministar pravosuđa i uprave, Ministarstvo pravosuđa i uprave, Ulica grada Vukovara 49, 10000 Zagreb; ivan.malenica@mpu.hr;

ORCID ID: orcid.org/0000-0003-4480-0336 


\section{UVOD}

Cilj ovog rada je pridonijeti znanstvenoj analizi instituta izvršenja upravnosudskih odluka na način da detaljno promotrimo rješenja iz francuskog pravnog sustava. Naime, s obzirom na to da je Republika Francuska predstavnica europsko-kontinentalnog sustava upravnosudske zaštite, koji je zastupljen i u Republici Hrvatskoj, ali i kolijevka upravnog prava, svakako je važno analizirati pravno uređenje izvršenja upravnosudskih odluka u toj državi. Naime, važno je podsjetiti kako neprekidni razvoj upravnog prava traje u Francuskoj još od 13. stoljeća pa sve do danas, a francuska je pravna teorija, zajedno sa sudskom praksom, kreirala brojne institute upravnog prava. Upravo i institut upravnog spora vuče podrijetlo iz Francuske, gdje ga je francuska upravnopravna teorija i praksa oblikovala u jedan od temeljnih instrumenata nadzora nad upravom. Temeljni propis koji uređuje upravni spor u Francuskoj jest Zakonik o upravnom sudovanju (Code de Justice Administrative). ${ }^{1}$

Već samim člankom L 11 Zakonika o upravnom sudovanju Republike Francuske ističe se izvršnost upravnosudskih odluka. ${ }^{2}$

Obveza koja upravi nalaže izvršenja upravnosudskih odluka, i to osobito onih koje donose niži upravni sudovi (prvostupanjski upravni sudovi ${ }^{3}$ i žalbeni upravni sudovi ${ }^{4}$ ), spominje se i u dvjema uzastopnim okružnicama od 23. lipnja

1 https://www.legifrance.gouv.fr/affichCode.do?cidTexte=LEGITEXT000006070933 (7. rujna 2020.).

2 Vidi članak L 11 Zakonika o upravnom sudovanju Republike Francuske: "Presude su izvršne."

3 "Upravnih sudova je 42, od kojih je 31 u najvećim francuskim gradovima, a 11 u prekomorskim teritorijima. Imaju oko 1000 sudaca (magistrats), čiji je pravni status utvrđen Uredbom od 28. rujna 1988., a neovisnost Zakonom od 6. siječnja 1986. U načelu se regrutiraju iz ENA-e i putem dodatnih natječaja. Njihov se ustroj temelji na Zakonu o upravnim sudovima i prizivnim upravnim sudovima (Code des tribunaux administratifs et des cours administratives d'appel). Nakon što su 1953. osnovani upravni sudovi kako bi se rasteretio Državni savjet, trideset godina poslije, odnosno 1980., on se opet našao zatrpan mnogobrojnim žalbama, tako da se nijedan predmet nije mogao riješiti brže od tri godine nakon podnošenja tužbe. Stoga je Zakonom od 31. prosinca 1987., kako bi se poboljšala ta situacija, predviđeno da se na međuregionalnoj razini osnuju prizivni upravni sudovi." Vidi Britvić Vetma, B., Upravno sudovanje u Francuskoj - što možemo naučiti, u: Koprić, I. (ur.), Europeizacija upravnog sudovanja u Hrvatskoj, Institut za javnu upravu, Zagreb, 2014., str. 235.

4 "Drugostupanjski upravni sud koji odlučuje o žalbenim navodima na odluke prvostupanjskih upravnih sudova. Na odluke prvostupanjskih upravnih sudova može se podnijeti žalba pred prizivnim upravnim sudovima, čije su odluke podložne reviziji s obzirom na pravno pitanje pred Državnim savjetom. U toj ulozi Državni savjet 
1987. (ministra unutarnjih poslova poslanoj prefektima) i od 13. listopada 1988. (predsjednika vlade članovima vlade). ${ }^{5}$

Takva izvršna obveza savršeno je u skladu s važnom sudskom praksom Suda u Strasbourgu, koji uključuje pravo na izvršenje sudskih odluka među procesne zahtjeve koji proizlaze iz članka 6. stavka l. Europske konvencije za zaštitu ljudskih prava": "Izvršenje presude ili rješenja bilo kojeg suda treba se smatrati sastavnim dijelom sudskog postupka u smislu članka 6.” (§ 40), osobito u kontekstu upravnog spora, u slučaju tužbe za poništenje pred najvišim upravnim sudom u državi, u cilju "učinkovite zaštite stranke i uspostave zakonitosti koji podrazumijevaju obvezu uprave da se pokori presudi ili rješenju koje izriče neki sud" (§ 4l). U skladu s presudom Golder protiv Ujedinjene Kraljevine od 21. veljače 1975. o pravu na pristup sudu, ta načelna odluka Hornsby protiv Grčke od 19. ožujka 1997. uključuje pravo na izvršenje sudskih odluka u opća jamstva pravičnog postupka, prema rješenju koje se od tada trajno preuzima i navodi. ${ }^{7}$

samo provodi nadzor nad ispravnom primjenom poslovnika i materijalnoga prava u sudskim odlukama koje se osporavaju. Prizivnih sudova ima osam: Bordeaux, Douai, Lyon, Marseille, Nancy, Nantes, Pariz, Versailles. Oni se dalje dijele na odjele. Broj i područje specijalizacije razlikuje se ovisno o članovima suda i odabiru unutarnje strukture koju provodi inspektor suda." Gjidara, M.; Britvić Vetma, B., Hrvatsko-francuski upravnopravni pojmovnik s prilozima, drugo, izmijenjeno i dopunjeno izdanje, Pravni fakultet Sveučilišta u Splitu, Sveučilište Panthéon-Assas, Paris 2, Split - Paris, 2018., str. 43.

5 Objavljene u Službenom glasniku Francuske Republike.

6 Narodne novine, Međunarodni ugovori, br. 18/1997, 6/1999, 14/2002, 13/2003, 9/2005, 1/2006, 2/2010.

7 "Uistinu, u samoj formulaciji članka 6. stavka 1. Europske konvencije o ljudskim pravima ne stoji da države potpisnice imaju obvezu izvršenja sudskih odluka, ali je logično da ona u ime prvenstva prava ili težnje za učinkovitošću prava na pristup sudu sudjeluje u definiciji pravičnog postupka. Drugim riječima, povreda obveze koja proizlazi iz dinamičnog tumačenja članka 6. stavka 1. od strane sudaca u Strasbourgu predstavlja, čitavo desetljeće, povredu prava na pravično suđenje jednako kao i povreda obveze za nepristranošću ili obveze suđenja u razumnom roku. Pravo na izvršenje sudskih odluka na taj način pridonosi tako da jamči pravo na pravično suđenje i na taj način daje novu dimenziju kvaliteti sudovanja. Izvršenje upravnosudskih odluka smatra se sastavnim dijelom suđenja, a neizvršenje presuda u razumnom roku posebno se kvalificira kao povreda "prava na sud" iz članka 6. stavka 1. Europske konvencije za zaštitu ljudskih prava.” Britvić Vetma, B., Kvaliteta odluka upravnih sudova, u: Hrvatsko-francuski upravnopravni dani, Hrestomatija II, Upravno sudovanje: nacionalni i usporedni aspekti, Pravni fakultet Sveučilišta u Splitu, Sveučilište Panthéon-Assas, Paris II, Državni savjet Republike Francuske, Split Paris, 2016., str. 157 - 182. 
Nakon presude Suda iz Strasbourga Hornsby protiv Grčke Ustavno vijeće Republike Francuske ${ }^{8}$ imalo je priliku u svojem rješenju Borba protiv isključivanja od 29. srpnja 1998. navesti posljedice izvršnosti svih sudskih odluka, a posebice upravnosudskih. Tako se u spomenutom rješenju navodi:

"Budući da svaka sudska odluka ima izvršnu snagu, tako svaka presuda može dovesti do prisilnog izvršenja, a tijelo za provedbu zakona treba, ako se to zahtijeva, pružiti pomoć pri tom izvršenju. S obzirom da je to pravilo posljedica načela podjele vlasti iz članka 16. Deklaracije o pravima čovjeka i građanina, i ako u izvanrednim okolnostima koje se odnose na očuvanje javnog poretka upravno tijelo može, bez ugrožavanja ranije navedenog načela, ne pružiti svoju pomoć pri izvršenju upravnosudske odluke, zakonodavac ne može podrediti pružanje te pomoći obavljanju upravnih koraka."

Takvo neizvršenje upravnosudske odluke povlači odgovornost države za štetu bez greške na temelju narušavanja jednakosti pred javnim rashodima i u uvjetima sadržanima u sudskoj praksi.

Kao što je već navedeno, Zakonik o upravnom sudovanju u čl. L9 11 jasno propisuje da su presude izvršne. Procesne metode koje se koriste u slučaju ne-

8 "Francuska ustanova utemeljena Ustavom pete Republike od 4. listopada 1958. nadzire regularnost nacionalnih izbora i referenduma. Na zahtjev izjašnjava se (očituje se) o usklađenosti zakona i nekih propisa s Ustavom. Također, u nekim okolnostima uključuje se u javni i parlamentarni život. Ustavno vijeće ima devet članova, od kojih se trećina zamjenjuje svake tri godine. Članovi se imenuju na jednokratno razdoblje od devet godina. Tri člana imenuje predsjednik Republike i po tri predsjednici obaju domova Parlamenta (Senata i Nacionalne skupštine). Ustavno je vijeće stalno tijelo iako se sastaje ovisno o količini posla koju dobiva. Nema odjele te zasjeda i odlučuje samo na sjednicama cijelog Vijeća. Na raspravama je potreban kvorum, tj. treba biti prisutno sedam sudaca. Ne objavljuju se izdvojena mišljenja. Izvanredne ustavne revizije uvedene su 1. ožujka 2010. stupanjem na snagu "prethodnoga pitanja ustavnosti”. Od toga dana svaki tužitelj ili tuženik tijekom sudskog postupka može osporiti neku zakonodavnu odredbu koja nije u skladu s pravima i slobodama zajamčenim Ustavom. Predmet se može uputiti Ustavnom vijeću uz prethodno odobrenje Državnog savjeta ili Kasacijskog suda. Ono mora dati svoje mišljenje u roku od tri mjeseca. Ustavno vijeće odlučuje o zakonitosti izbora predsjednika Republike i referenduma te proglašava rezultate. Odlučuje i o zakonitosti izbora članova obaju domova Parlamenta i pravila kojima se uređuju kvalificiranost i diskvalificiranje. Odlučuje i o zakonitosti izbora članova obaju domova Parlamenta i pravila kojima se uređuje kvalificiranost i diskvalificiranje.” Više o tome vidi u: Gjidara; Britvić Vetma, op. cit. u bilj. 4, str. 29 - 33.

9 Odredbe koje su sadržane u legislativnom dijelu Zakonika o upravnom sudovanju Republike Francuske (Partie legislative) označavaju se slovom L. 
izvršenja upravnosudskih odluka kreću se od poticajnih mjera do prinudnih mjera i na kraju do samih represivnih mjera.

Snažan doprinos efikasnom izvršenju upravnosudskih odluka u Republici Francuskoj dale su dvije institucije, Odjel za izvješća i studije Državnog savjeta i Pučki pravobranitelj. Uglavnom se to odnosi na situacije kada se javnopravno tijelo suoči s teškoćama prilikom izvršenja sudske odluke, a posebice s neizvjesnošću glede ispravnog tumačenja sudske odluke. ${ }^{10}$

\section{POSTUPAK PRED ODJELOM ZA IZVJEŠĆA I STUDIJE}

Povijesno gledajući, Odjel za izvješća i studije Državnog savjeta ${ }^{11}$ bio je prvi korak u ostvarivanju načela bolje učinkovitosti upravnosudskih odluka, a podredno tome i efikasnijem izvršenju. ${ }^{12}$ Ovo je tijelo osnovano Dekretom od 30. srpnja 1963. godine pod nazivom Povjerenstvo za izvješća, prvotno kao posebni upravni odjel Državnog savjeta, te je kasnije donošenjem brojnih dekreta kojima je uređivano ustrojstvo i nadležnost, evoluiralo preko Povjerenstva za izvješća i studije ${ }^{13}$ do današnjeg Odjela za izvješća i studije, čije su se ovlasti postupno proširivale te se shodno tome kontinuirano povećavao i broj aktivnosti. ${ }^{14}$ Iako je ovaj sustav ponajprije bio osnovan i osmišljen kao pomoć pri izvršavanju presuda Državnog savjeta, on se zbog svoje učinkovitosti počeo primjenjivati i

10 Vidi Malenica, I., Izvršenje upravnosudskih odluka u hrvatskom i poredbenom pravu, doktorska disertacija, Pravni fakultet Sveučilišta u Zagrebu, Zagreb, 2020., str. 25.

11 "To je tijelo po svom karakteru upravni odjel. Ipak, posebnost njegovih zadataka dovela je do toga da on ima originalnu strukturu, inspiriranu komisijom koju je naslijedio. S jedne strane, on ima generalnog izvjestitelja, čiji je zadatak da, zajedno s predsjednikom, priprema godišnji izvještaj i upravlja akcijama koje se tiču izvršenja sudskih odluka. S druge strane, a to nije predviđeno u pisanim izvorima, njegovi članovi pripadaju i drugim odjelima, kao što je odjel za sporove, koji u nju uglavnom delegira zamjenika predsjednika, javnog izvjestitelja i stručnog suradnika, tako i savjetodavne odjele koji su u njemu predstavljeni s po dvojicom ili trojicom savjetnika. Nekoliko izvjestitelja, ali na nepotpuno radno vrijeme, koji istovremeno pripadaju odjelu za sporove, tretira teške slučajeve izvršenja." Gjidara; Britvić Vetma, op. cit. u bilj. 4, str. 130 - 131 .

O ovom tijelu vidi više u: Gjidara, M., La fonction administrative contentieuse, L.G.D.J., Paris, 1972., str. 329.

Dekret od 28. siječnja 1969. godine.

14 Dekret od 26. kolovoza 1975. godine, od 24. ožujka i 22. studenoga 1976., od 12. svibnja 1981. godine, od 24. siječnja 1985. godine, od 2. rujna 1988. godine. 
na presude upravnih sudova, a zatim se njegova primjena proširila i na ostale upravne sudove kako bi se omogućilo izvršavanje svih njihovih odluka. ${ }^{15}$

Od 1963. godine, kada je osnovan Odjel, on je prvotno imao zadaću odgovoriti na zahtjeve za pojašnjenja zainteresiranim ministrima, ali i na prigovore podnositelja zahtjeva. Tijekom godina Odjel za izvješća i studije Državnog savjeta postajao je sve aktivniji i važniji, što je pokazivao brojnim studijama koje je taj Odjel proveo i koje su imale snažan utjecaj na zakonodavstvo, ali i na upravnopravne predmete koje je obrađivao. Posebno je važno njegovo godišnje izvješće vladi i parlamentu, koje se objavljuje od 1987. godine, a u kojem Odjel daje veoma poučan pregled odnosa između upravnog sudovanja i same uprave. Sauvé ističe da su u pogledu izvršenja Povjerenstvo, a zatim Odjel za izvješća i studije, predstavljali bitan korak u razmatranju problema izvršenja kroz razna sredstva koja se koriste, počevši od pomoći i savjeta pa do stigmatiziranja. ${ }^{16}$

\subsection{Zahtjev za pojašnjenjem sudske odluke}

Od 1963. godine pred Državnim savjetom, a dekretima donesenima 1969. i 1988. godine i pred svim upravnim sudovima, uprava može tražiti pojašnjenje o smislu donesene odluke, o dosegu pojedine odluke i praktičnoj pomoći za izvršenje. Na temelju članka $\mathrm{R}^{17}$ 931-I Zakonika o upravnom sudovanju postupak pred Odjelom za izvješća i studije pokreće se zahtjevom koji podnosi javnopravno tijelo koje treba izvršiti neku konkretnu odluku upravnog suda i u kojem ono zahtijeva pojašnjenje o načinu implementacije konkretne sudske odluke. Najčešće je riječ o situacijama kada je sudska odluka nejasna, neodređena ili je potrebno primijeniti neki novi propis. Ovaj postupak pruža mogućnost dobivanja pojašnjenja o implementaciji sudske odluke koju je upravni ili specijalizirani upravni sud donio na štetu javnopravnog tijela.

Odgovor na zahtjev za pojašnjenjem sudske odluke upućen Državnom savjetu daje Odjel za izvješća i studije, a kod upravnih sudova predsjednik suda koji pak može imenovati izvjestitelja ili, ako je potrebno, uputiti zahtjev Odjelu

15 Gjidara, M., Les causes d' inexécution des décisions du juge administratif et leurs remèdes, Zbornik radova Pravnog fakulteta u Splitu, vol. 52, br. 1, 2015., str. 83.

16 Sauvé, J. M., Etat de droit et efficacité, Actualité Juridique de droit administratif (A.J.D.A.), Paris, posebno izdanje srpanj-kolovoz 1999., str. 127.

17 Odredbe sadržane u regulatornom dijelu Zakonika o upravnom sudovanju (Partie réglementaire-Décrets en Conseil d'État) označene su slovom R (règlement). 
za izvješća i studije. ${ }^{18}$ Osim zahtjeva za pojašnjenjem sudske odluke Odjel za izvješće i studije postupa i na temelju prigovora tužitelja na izvršenje. ${ }^{19}$

U praksi je mali broj zahtjeva za pojašnjenjem, iako može varirati od godine do godine, koji se upućuju Odjelu za izvješća i studije. Tako je primjerice tijekom 2014. godine upućen dvadeset i jedan zahtjev, trinaest u 2007. i sedam u 2010. ${ }^{20}$

Naglašavamo da je riječ o postupku koji se odnosi na Državni savjet, odnosno na Odjel za izvješća i studije, a imenovani izvjestitelj obavlja svoju zadaću pod nadležnosti predsjednika tog upravnog odjela. No, ako izvršnost upravnosudske odluke omogućuje da se zahtjev za pojašnjenje odnosi na nepravomoćnu odluku, Državni savjet ne može donijeti odluku dok je u tijeku postupak izricanja novčane kazne u upravnosudskom postupku. Svi predmeti za koje se upućuje zahtjev za pojašnjenjem mogu se navesti u godišnjem izvješću Državnog savjeta s napomenom o danom odgovoru. ${ }^{21}$

\subsection{Zahtjev za pomoć pri izvršenju}

Također, kao mehanizam podrške pri izvršenju, stranke imaju na raspolaganju i zahtjev za pomoć pri izvršenju. U odnosu na zahtjev za pojašnjenjem sudske odluke ovaj se mehanizam koristi u naprednijoj fazi u slučaju poteškoća pri izvršenju. Stranke u postupku, ali i sve zainteresirane osobe, uključujući i treće osobe, mogu pokrenuti postupak pred sudom kako bi im on pomogao odrediti način za izvršenje. Zahtjev za pomoć pri izvršenju može se podnijeti nakon proteka roka od tri mjeseca od kada je sudska odluka dostavljena. Rok od tri mjeseca vrijeme je u kojem je javnopravno tijelo trebalo izvršiti sudsku odluku. No zahtjev za pomoć pri izvršenju može se podnijeti i prije isteka roka

18 Gjidara, op. cit. u bilj. 15, str. 84.

19 Vidi o tome u: Malenica, op. cit. u bilj. 10, str. 25 - 26.

20 https://www.conseil-etat.fr/ressources/avis-aux-pouvoirs-publics/consiliaweb (15. rujna 2020.).

21 Primjerice, odgovor Odjela za izvješća i studije od 3. prosinca 1997. na zahtjev za pojašnjenjem koji je uputio ministar unutarnjih poslova s obzirom na posljedice značajne presude Avriller od 1. listopada 1997. o posljedicama koje se odnose na ugovor o dodjeli usluga pitke vode i sanacijskih usluga grada Grenoblea o tome da je Državni savjet poništio odluku gradskog vijeća kojom se gradonačelnika ovlašćuje da potpiše taj ugovor. 
od tri mjeseca u slučaju da javnopravno tijelo izričito odbija izvršiti sudsku odluku ili kada upravnosudska odluka određuje provođenje neke hitne mjere..$^{22,23}$

Nakon primitka zahtjeva za pomoć pri izvršenju predsjednik Odjela za izvješća i studije angažira suca izvjestitelja koji će provesti sve potrebne radnje koje on smatra korisnim kako bi se izvršila sudska odluka na koju se odnosi zahtjev. U prvoj fazi sudac izvjestitelj provodi, u svrhu obrade zahtjeva, određene neformalne radnje (putem dopisa ili razgovora). Postupak će završiti ako je zahtjev ispunjen ili ako se smatra neutemeljenim. Ako do toga ne dođe, na inicijativu predsjednika Odjela za izvješća i studije počinje postupak pred Odjelom za sporove kada je riječ o Državnom savjetu, a postupak se može na temelju naloga predsjednika Odjela nastaviti i pred upravnim ili žalbenim upravnim sudovima. ${ }^{24}$

\section{POSTUPAK PRED PUČKIM PRAVOBRANITELJEM}

Zakonom od 24. prosinca 1976. godine zakonodavac je proširio ovlast Pučkog pravobranitelja stavljajući mu u nadležnost rješavanje problema neizvršenja pravomoćnih sudskih odluka. Ovlast koja je bila dana Pučkom pravobranitelju odnosila se na mogućnost izdavanja naloga javnopravnom tijelu koji je imao za svrhu prisiliti javnopravno tijelo na izvršenje sudske odluke. No taj nalog nije imao sankciju u slučaju nepostupanja javnopravnog tijela, već je u tom slučaju Pučki pravobranitelj imao mogućnost izrade posebnog javnog izvješća koje bi se objavljivalo u javnom glasilu i predstavljalo je javnu prijavu protiv javnopravnog tijela koje nije izvršilo sudsku odluku. Međutim, pokretanje postupka pred Pučkim pravobraniteljem nije isključivalo mogućnost pokretanja postupka pred Odjelom za izvješća i studije. Štoviše, ova dva tijela mogla su i koordinirano djelovati na način da izrade posebno izvješće o konkretnom slučaju.

Zakonom od 23. srpnja 2008. godine Pučkog pravobranitelja zamijenio je Branitelj prava (Défenseur des droits) koji na temelju tog propisa koji je i danas na snazi može izdavati preporuke o poštovanju prava i sloboda koja, među ostalim, obuhvaćaju i pravo izvršenja pravomoćne presude.

22 R 931-2 Zakonika o upravnom sudovanju.

23 “Zakonom od 30. lipnja 2000. godine omogućeno je upravnom sucu da radi zaštite prava stranaka u hitnom slučaju naredi bilo koju mjeru kojom se može spriječiti pogoršanje štetnog stanja ili produženje nezakonite situacije, a pod uvjetom da se njome ne ometa izvršenje upravnoga akta." Gjidara; Britvić Vetma, op. cit. u bilj. 4, str. 116.

24 Vidi o tome Malenica, op. cit. u bilj. 10, str. 26 - 27. 
Međutim, kako se postupak pred Odjelom za studije i izvješća i Pučkim pravobraniteljem, a kasnije i pred Braniteljem prava, pokazao u određenim situacijama nedostatnim, javila se potreba za uvođenjem određenih prisilnih mjera kako bi se riješio problem neizvršenja sudskih odluka. ${ }^{25}$

\section{PRISILNE MJERE ZA IZVRŠENJE UPRAVNOSUDSKIH ODLUKA}

Zakon od 16. srpnja 1980. godine o periodičkim novčanim kaznama izrečenim u upravnim postupcima i izvršenju presuda od strane pravnih osoba javnog prava $^{26}$ i Zakon od 8. veljače 1995. godine o organizaciji sudova u građanskom, kaznenom i upravnom postupku u bitnome su utjecali na daljnji razvoj sustava učinkovitog izvršenja upravnosudskih odluka. Ovim su zakonima Državnom savjetu, a kasnije i upravnim sudovima i žalbenim upravnim sudovima, stavljena na raspolaganje određena prisilna sredstva kako bi se javnopravnim tijelima nametnula obveza poštovanja sudskih odluka, i to posebice onih koje su donesene na štetu javnopravnom tijelu. Ova dva zakona predstavljaju prethodnicu Zakoniku o upravnom sudovanju, koji je u knjizi IX ${ }^{27}$ uredio pitanje izvršenja upravnosudskih odluka. Kako bi se riješio problem neizvršenja upravnosudskih odluka, Zakonik o upravnom sudovanju propisuje dva pravna instrumenta, i to periodička novčana kazna i nalog o izvršenju (injonction d'exécution). ${ }^{28}$

\subsection{Periodička novčana kazna}

Kako smo i prethodno naveli, Zakonom od 16. srpnja 1980. godine ${ }^{29}$ prvi je put u francusko upravno sudstvo uveden institut periodičke novčane kazne kao sredstvo koje je bilo namijenjeno kao pomoć u izvršavanju sudske odluke. Zakonik o upravnom sudovanju donesen 2000. godine u knjizi IX. uređuje taj instrument koji se koristi uslijed neizvršenja upravnosudskih odluka. Ovim pravnim sredstvom prisiljava se javnopravno tijelo koje namjerno i ustrajno

25 Ibid., str. $27-28$.

26 Loi $n^{\circ}$ 80-539 du 16 juillet 1980 relative aux astreintes prononcées en matière administrative et à l'exécution des jugements par les personnes morales de droit public, https://www.legifrance.gouv.fr/affichTexte.do?cidTexte=JORFTEXT000000705334 (2. srpnja 2018.).

27 Riječ je o dijelu Zakonika o upravnom sudovanju (članak L 911-1 do članak L 91 1-10).

28 Vidi Malenica, op. cit. u bilj. 10, str. 28.

29 Ovaj Zakon proširen je i pojašnjen dekretima od 12. svibnja 1981. godine, 11. travnja 1988. godine i 15. svibnja 1990. godine. 
odbija izvršiti sudsku odluku na njezino izvršenje. Chapus dodaje da je riječ o prisilnoj pomoćnoj mjeri u slučaju neizvršenja koja ne sadržava izričit nalog javnopravnom tijelu u slučaju neizvršenja sudske odluke. ${ }^{30}$

Periodička novčana kazna predstavlja novčani iznos kojim se može kazniti javnopravno tijelo u slučaju neizvršenja sudske odluke. Ponajprije, njezino izricanje (određivanje) predstavlja prijetnju novčanom kaznom javnopravnom tijelu kada ono pokazuje nespremnost izvršenja upravnosudske odluke. Ona je neovisna o eventualnoj naknadi štete zbog neizvršenja sudske odluke te ima cilj spriječiti neizvršenje sudske odluke. Prema Zakoniku o upravnom sudovanju, u slučaju da javnopravno tijelo ne izvrši upravnosudsku odluku, stranka može zatražiti od upravnog suda ili žalbenog upravnog suda koji je donio odluku da se pobrine da se ta odluka i izvrši. Postupajući na temelju zahtjeva stranke sud može od javnopravnog tijela zatražiti izvršenje sudske odluke u određenom roku prijeteći periodičkom novčanom kaznom u slučaju daljnjeg neizvršenja. ${ }^{31}$

Osim određivanja periodičke novčane kazne a posteriori, Zakonik o upravnom sudovanju daje mogućnost Državnom savjetu da izriče periodičku novčanu kaznu a priori, odnosno prilikom donošenja upravnosudske odluke. Dakle, mogućnost izricanja periodičke novčane kazne ovisi o zahtjevu stranke i slobodnoj ocjeni suca. Također, periodička novčana kazna u prvom bi redu trebala biti privremenog karaktera, no ako sudac to odluči, može postati i konačna. ${ }^{32}$ Iznos periodičke novčane kazne ne mora se u cijelosti isplatiti stranci, jer se jedan dio može uplatiti i u državni proračun, osim u slučaju kada se periodička novčana kazna izriče Republici Francuskoj (državi) - tada cijeli iznos ide stranci na koju se presuda odnosi. ${ }^{33}$ Presuda kojom je izrečena periodička novčana kazna te odluka kojom se određuje periodička novčana kazna dostavljaju se državnom odvjetniku koji djeluje u okviru Suda za proračunsku disciplinu. ${ }^{34}$

\subsubsection{Novčana kazna}

Novčana kazna, kao i nalog, prisilno je sredstvo koje se primjenjuje protiv uprave. Takvo se rješenje ponavlja čak i nakon Zakona od 16. srpnja 1980. o

30 Chapus, R., Droit du contentieux administratif, 12ème ed., Montchrestien, Paris, 2006., str. 1137.

31 L 911-4 Zakonika o upravnom sudovanju.

32 L 911-6 Zakonika o upravnom sudovanju.

33 Državni savjet, presuda u predmetu Fédération française des masseurs/kinésithérapeutes (Francuski savez fizioterapeuta/masera) od 28. veljače 2001.

34 Vidi o tome u: Malenica, op. cit. u bilj. 10, str. 29 - 30. 
novčanim kaznama izrečenim u upravnim pitanjima i o tome da javnopravne osobe izvršavaju presude, izvan prisilne naplate u području primjene zakona, $u$ svim ostalim slučajevima u kojima je uprava dužna donijeti izvršne mjere. Ovo isto rješenje i dalje se nameće, protiv primjene novčane kazne, pred sudom za sporove o sukobu nadležnosti i pred redovitim sudom, uključujući i sve ono što se odnosi na spor o građanskopravnoj odgovornosti industrijskih i gospodarskih javnih ustanova, čak i onih koje nemaju javno računovodstvo.

Točno ta izravna poveznica između novčane kazne i nalaganja također upućuje i na to da se ta dva postupka uostalom mogu učinkovito kombinirati, što je predviđeno člankom L 911-3 Zakonika o upravnom sudovanju:

"Kada se pred sudom pokrene postupak zbog zahtjeva u tom smislu, sud može $u$ istoj odluci uz naredbu propisanu člancima L 911-1 i L 911-2 priložiti jednu zateznicu (sporednu novčanu kaznu) koju izriče pod uvjetima predviđenim ovom knjigom te određuje datum njezina stupanja na snagu."

Međutim, prethodno spomenuti Zakon od 16. srpnja 1980. uključio se u smisao prijenosa načina izvršenja iz privatnog prava u upravni spor. Tada je bila riječ o uvođenju prvog postupka novčane kazne kao pomoći pri izvršenju odluke koju je donio prvostupanjski upravni sud, odnosno upravni sud.

No, istovremeno s nametanjem upravnosudskog nalaganja, Zakonom od 8. veljače 1995. uveden je i drugi postupak novčane kazne, koji je odmah proširen na cijeli upravni i upravnosudski postupak, kao podrška upravnosudskom nalaganju zbog toga što upravni sud nije izvršio pravomoćnu presudu.

Međutim, u oba slučaja postoje zajednički postupovni elementi, a praksa koja se odnosi na novčanu kaznu ostaje vrlo ograničena.

4.1.1.1. Postupak u kojem se izriče novčana kazna kao pomoć pri izvršenju upravnosudskih odluka pred Državnim savjetom

Mehanizam iz izmijenjenog Zakona od 16. srpnja 1980. preuzet je člankom L 91 1-5, stavak 1. Zakonika o upravnom sudovanju:

"U slučaju neizvršenja odluke upravnih sudova Državni savjet može i na vlastitu inicijativu izreći zateznicu javnopravnim tijelima ili tijelu privatnopravnog karaktera nadležnom za obavljanje javne usluge kako bi se osiguralo izvršenje odluke." 35

35 Članak L 911-5, stavak 2. i 3.:

“Odredbe prvog stavka ne primjenjuju se u situacijama propisanim člancima L 91 1-3

i L 911-4 i kada je Državni savjet rješavajući u sporovima već primijenio odredbe članaka L 911-1 i L 911-2. 
Međutim, ovaj mehanizam, dopunjen izvedenim propisima, ne može se primijeniti u slučajevima koje predviđa članak L 911-3 (kombinacija postupaka izricanja nalaganja i novčane kazne) ${ }^{36}$ i članak L 91 l-4 (novčana kazna kao pomoć pri izvršenju upravnosudske odluke pred nižim sudovima) ${ }^{37}$ te kada je Državni savjet pri rješavanju spora već primijenio odredbe iz članaka L 911-1 (upravnosudsko nalaganje za izvršenje u određenom smislu) ${ }^{38}$ i članka L 91 1-2 (upravnosudsko nalaganje za izvršenje u određenom roku) ${ }^{39}$.

Nadalje, trebamo razlikovati dva sredstva koja se mogu koristiti kao pomoć pri izvršenju upravnosudske odluke pred nadležnim upravnim sudom (može ih se i kombinirati): 1. izvršenje mirnim putem, 2. izvršenje upravnosudskim putem.

Rješavanje postupka mirnim putem smješta se uz postupak izricanja novčane kazne. U rješavanju mirnim putem glavni zahtjev za pomoć pri izvršenju upravnosudske odluke podnose "zainteresirane strane". ${ }^{40}$ Prema tome, rješavanje mirnim putem obuhvaća zahtjeve za pomoć pri izvršenju koje podnose svi tužitelji kojima je odluka upravnog suda pružila zadovoljštinu, a da uprava tu odluku nije izvršila. Tada je potrebno da kada stranka pokrene postupak

Ovlasti koje je ovaj članak dodijelio Državnom savjetu može obavljati predsjednik Odjela za sporove."

36 "Na temelju zaključaka u tu svrhu sud može u istoj odluci uz naredbu propisanu člancima L 911-1 i L 911-2 priložiti jednu zateznicu (sporednu novčanu kaznu) koju izriče pod uvjetima predviđenim ovom knjigom te određuje datum njezina stupanja na snagu."

37 "U slučaju neizvršenja neke presude zainteresirana stranka može zatražiti od upravnog suda ili žalbenog suda koji je donio presudu da osigura i njezino izvršenje."

38 "Kada odluka obvezno podrazumijeva donošenje neke konkretne izvršne mjere od strane javnopravnog tijela ili tijela privatnopravnog karaktera koje je odgovorno za obavljanje neke javne usluge, sud prema predloženim zaključcima propisuje istom odlukom odgovarajuću mjeru te prema potrebi i rok za izvršenje."

Članak L 911-1-1: “Kada primjenjuje članak L 911-1, sud može naložiti vraćanje na radno mjesto bilo koje osobe koja je bila predmet otkaza, neobnavljanja ugovora o radu ili opoziva protivno odredbama drugog stavka članka L 4122-4 Zakona o obrani, drugog stavka članka L 1132-3-3 Zakona o radu ili drugog stavka članka 6. ter A Zakona br. 83-634 od 13. srpnja 1983. o pravima i obvezama dužnosnika, uključujući i situacije kada je ta osoba bila vezana ugovorom o radu na određeno vrijeme s javnopravnim tijelom ili tijelom privatnopravnog karaktera nadležnog za obavljanje javne usluge."

39 "Kad odluka obvezno podrazumijeva da javnopravno tijelo ili tijelo privatnopravnog karaktera nadležno za obavljanje javne usluge ponovno donese odluku nakon novog ispitnog postupka, sud na temelju zaključaka u tu svrhu propisuje istom sudskom odlukom da se ta nova odluka mora donijeti u određenom roku."

40 Pojam proširen na osobe na koje se upravnosudska odluka izravno odnosi. 
pred Odjelom za izvješća i studije po proteku roka od tri mjeseca (presuda nije izvršena) računanje roka započinje danom dostave ili ako je riječ o žurnim mjerama bez odgode. U tom okviru ispunjavaju se svi oni postupci koji se smatraju korisnima kako bi Državni savjet izvršio sudsku odluku.

Prema Odjelu za izvješća i studije Državnog savjeta, ponajprije je riječ o razvijenijoj upravnoj fazi postupka izvršenja.

Upravnosudski postupak predstavlja nastavak rješavanja mirnim putem i u perspektivi novčane kazne. Ako rješavanje mirnim putem nije dovoljno, otvara se ovaj upravnosudski put koji vodi do propisivanja točnih mjera popraćenih novčanom kaznom po danu zakašnjenja. Ovaj postupak preuzima Odjel za sporove. No, može ga preuzeti i predsjednik Odjela za sporove koji odluku donosi i utemeljuje na obrazloženom rješenju. Nadalje, Odjel za izvješća i studije ga može iskoristiti po službenoj dužnosti. Ipak, tužitelj također može preskočiti rješavanje mirnim putem i izravno prijeći na upravnosudski postupak tako što će sam podnijeti zahtjev za novčanom kaznom nakon što šest mjeseci upravnosudska odluka nije izvršena ili ako je riječ o žurnim mjerama bez odgode.

\subsubsection{Naknadno dekoncentriranje postupka izricanja novčane kazne prema nižim sudovima}

Upravnosudski postupak nastavlja se na postupak mirnog rješavanja i u perspektivu izricanja novčane kazne. Usprkos svojim promjenama, postupak izricanja novčane kazne kao pomoć pri upravnosudskom izvršenju, pred samim Državnim savjetom mogao se činiti prekompliciranim ili prerestriktivnim. Prema tome, zakonodavac uvodi novo unapređenje 1995. s ciljem dekoncentriranja i prenošenja, koliko je to moguće, postupka izricanja novčane kazne kao pomoć pri izvršenju odluka upravnih sudova. ${ }^{41}$

$\mathrm{Na}$ taj način provedena dekoncentracija u korist nižih sudova provodi se prema jednostavnom sustavu preraspodjele:

- sud ili žalbeni sud brine se o izvršenju svojih konačnih odluka

- Žalbeni sud također se brine o izvršenju presuda koje su donijeli sudovi koji se nalaze u nadležnosti žalbenog suda i protiv kojih je podnesena žalba pred tim žalbenim sudom jer se izvršenje nikako ne može obustaviti zbog toga što uprava koristi to pravno sredstvo. Prema tome, u slučaju

41 Vidi o tome u: Gohin, O., Contentieux administratif, 7. izd., LexisNexis, Paris, 2012., str. $400-401$. 
žalbe, žalbeni je sud "jedini nadležan" "u svim slučajevima”, uključujući i situaciju u kojoj je žalba odbačena ili žalitelj odustane. ${ }^{42}$

U spomenuta dva slučaja članak L 911-4, stavak 3. Zakonika o upravnom sudovanju glasi:

"Ako presuda čije se izvršenje traži nije odredila provedbene mjere, sud koji razmatra taj zahtjev određuje i provedbene mjere. Sud može odrediti rok za izvršenje i zateznicu." ${ }^{\prime 3}$

Članak L 911-4 Zakonika o upravnom sudovanju primjenjuje samo upravnosudski put pred nižim upravnim sudovima, dok kodificirani provedbeni dekret od 3. srpnja 1995. u članku R 921-5 Zakonika o upravnom sudovanju omogućuje predsjedniku suda pred kojim je pokrenut postupak ili imenovanom izvjestitelju da poduzme "sve potrebne mjere", što omogućuje rješavanje mirnim putem. Međutim, članak R 921-6 Zakonika također omogućuje da se u spisu o sporu rješavanje mirnim putem i automatski vrati na upravnosudski put, s određivanjem ograničenog vremena za taj postupak, što ide u korist građanina u tri slučaja:

- ako predsjednik suda procijeni da je bez odgode potrebno što prije pribjeći upravnosudskom postupku

- u slučaju u kojem u mjesecu koji slijedi nakon odluke o obustavi njegova zahtjeva za izvršenjem koju provodi predsjednik predmetnog suda zainteresirana osoba ne prihvati tu obustavu te nastavi i dalje smatrati da upravnosudska odluka nije u potpunosti izvršena u onom dijelu koji se na njega odnosi

- “u svakom slučaju”, nakon šest mjeseci neuspješnog rješavanja mirnim putem počevši od pokretanja postupka pred sudom. ${ }^{44}$

Predsjednik žalbenog upravnog suda ili predsjednik upravnog suda rješenjem pokreće upravnosudski postupak. Naime, Zakonik o upravnom sudovanju navodi da predsjednik suda ili žalbenog suda odlučuje neobrazloženim rješenjem protiv kojeg "nije moguće podnijeti žalbu", a koje je prema tome akt upravnog sudovanja. Štoviše, postupak izricanja novčane kazne kao pomoć pri upravnosudskom izvršenju može dovesti do izricanja novčane kazne, ne samo na zahtjev zainteresirane strane, već i po službenoj dužnosti, pred nižim sudovima, a i pred samim Državnim savjetom.

\footnotetext{
42 Ibid., str. 401.

43 Zakonik o upravnom sudovanju Republike Francuske.

44 Gohin, op. cit. u bilj. 41, str. 402.
} 
Recipročno, u nadležnosti Odjela za izvješća i studije Državnog savjeta samo su zahtjevi za izricanjem novčane kazne kao pomoć pri upravnosudskom izvršenju:

- odluka Državnog savjeta

- odluka upravnih sudova i žalbenih upravnih sudova o upućivanju zahtjeva tih sudova Državnom savjetu

- presudâ upravnih sudova protiv kojih se ulaže žalba pred Državnim savjetom

- odluka specijaliziranih upravnih sudova protiv kojih se podnosi žalba u kasacijskom postupku pred Državnim savjetom, podložno posebnom ovlaštenju predmetnog suda u tu svrhu.

Ukratko, osim obveze plaćanja, podnositelj tužbe u načelu treba predati svoj zahtjev za izvršenje odluke upravnog suda nadležnom sudu koji je odluku donio, odnosno upravnom sudu, žalbenom upravnom sudu ili Državnom savjetu. Zatim slijede dva načina kao pomoć pri izvršenju upravnosudske odluke pred predmetnim sudom, koje treba dobro razlikovati, iako ih se može kombinirati - jedan mirnim putem, a drugi upravnosudskim putem. U prvoj, tzv. prijateljskoj fazi, predsjednik suda ispunjava sve administrativne mjere koje smatra potrebnima, a u drugoj, tzv. upravnosudskoj fazi, sud propisuje točne mjere pod prijetnjom novčane kazne po danu zakašnjenja. ${ }^{45}$

\section{NALOG O IZVRŠENJU}

Zakonom od 8. veljače 1995. godine omogućeno je sucima da u sporovima o poništenju izdaju naloge o izvršenju (injoction d'exécution), kojima upravi određuju konkretne mjere koje pravomoćna presuda sadržava, dajući joj prema potrebi određeni rok za izvršenje te izriču prijetnju periodičkom novčanom kaznom. Ovim Zakonom dana je sucu, u cilju veće učinkovitosti izvršenja njegovih odluka, čak i ovlast da prilikom donošenja odluke u upravnom sporu prepozna potrebne mjere koje poništenje podrazumijeva te ih izričito navede u svojoj odluci i eventualno nalogu pridoda prijetnju periodičkom novčanom kaznom. ${ }^{46}$ Riječ je, dakle, o mogućnosti poduzimanja određenih preventivnih

45 Ibid., str. 403.

46 Donošenje ovog zakona prema nekim autorima (kao što su Chapus, Gaudemet) dovodi u pitanje smisao razlikovanja spora o prekoračenju ovlasti i spora pune jurisdikcije jer je ovim zakonom sucu dana ovlast izdavanja naloga javnopravnom tijelu da izvrši njegovu odluku u određenom roku s mogućnošću određivanja i periodičke 
mjera za izvršenje i prije negoli u samoj primjeni upravnosudske odluke dođe do problema neizvršenja.

Državni savjet ima mogućnost donošenja naloga o izvršenju bez formalnog zaprimanja zahtjeva od same stranke ${ }^{47}$, a upravni sudovi i žalbeni upravni sudovi to mogu učiniti samo na izričit zahtjev tužitelja u sporu. Ova ovlast donošenja naloga dana je isključivo državnim savjetnicima ${ }^{48}$ te sucima upravnih sudova i žalbenih upravnih sudova.

Državni savjet može donijeti nalog a priori samo kada odlučuje u sporu pune jurisdikcije. Riječ je, dakle, o "nalaganju po službenoj dužnosti”, pri čemu sudac prilikom izrade meritorne upravnosudske odluke, nakon što je obrazloži, u izreci navodi da poništenje odluke podrazumijeva i obveze sadržane u obrazloženju, koje idu na teret ove ili one stranke. ${ }^{49}$ Riječ je, stoga, o donošenju naloga o izvršenju a priori. Gjidara dodaje da, iako se pitanje izvršenja upravnosudskih odluka postavlja tek nakon što se one donesu, ova zakonska ovlast omogućuje sucu da predvidi posljedice potencijalnog neizvršenja istovremeno s rješavanjem spora i štete koje zbog toga mogu nastati. Nadalje, navodi da sudac ispituje u svjetlu okolnosti slučaja hoće li se uprava pokoriti upravnosudskoj odluci bez problema ili pak treba odmah prilikom donošenja odluke izvršiti jači ili slabiji pritisak..$^{50}$ Sudac dakle procjenjuje hoće li pritisak prema javnopravnom tijelu u vezi s izvršenjem svoje (konkretne) odluke vršiti na način da prilikom donošenja odluke u upravnom sporu dodatnim nalogom odredi i rok u kojem je javnopravno tijelo dužno izvršiti odluku ili će tom roku pridodati i periodičku novčanu kaznu. Određivanje iznosa periodičke novčane kazne u diskrecijskoj je ovlasti suca, ali njezin iznos ne smije premašiti iznos koji zahtijevaju stranke. ${ }^{51}$ Stranka može zahtijevati izricanje periodičke novčane kazne tijekom trajanja čitavog postupka. U pravilu o zahtjevu odlučuje sud koji je donio odluku koja nije izvršena, a postupak pokrenut na temelju zahtjeva za izvršenje ne pred-

novčane kazne. Britvić Vetma, B., Upravni spor pune jurisdikcije, doktorska disertacija, Pravni fakultet u Splitu, Split, 2011., str. 114 - 115.

47 Riječ je o tzv. izvršenju po službenoj dužnosti (l'injonction d'office).

48 Državnim savjetnikom (Conseiller d'État) postaje se nakon 12 godina rada kao maître des requêtes. U Državnom savjetu članovi mogu obavljati sve funkcije. Međutim, što se tiče predsjednika u pododjelima i odjelima, njih mogu obavljati svi savjetnici. Članovi Državnoga savjeta postupno (redom) napreduju od "auditeur", "maître des requêtes" do državnog savjetnika.

49 Chapus, op. cit. u bilj. 30, str. 961.

50 Gjidara, op. cit. u bilj. 15, str. 96.

51 Courrèges, A.; Daël, S., Contentieux administratif, P.U.F., Thémis - droit, Paris, 2013. str. 341 . 
stavlja novi spor, već samo produljenje trajanja spora koji je doveo do odluke čije se izvršenje traži. ${ }^{52}$

Zakonik o upravnom sudovanju predviđa razdoblje čekanja i promatranja kako bi se sa sigurnošću moglo utvrditi da upravnosudska odluka nije izvršena. To razdoblje čekanja i promatranja iznosi od tri do šest mjeseci, ovisno o tome podnosi li se zahtjev za izvršenje upravnom sudu, žalbenom upravnom sudu ili Državnom savjetu.

U slučaju da je sud u svojoj odluci, čije se izvršenje traži, odredio rok u kojem je javnopravno tijelo dužno izvršiti svoju obvezu utvrđenu u odluci, zahtjev za izvršenje uzet će se u razmatranje tek nakon isteka roka za izvršenje. Ako je sudska odluka koja nije izvršena predmet žalbe, stranka će zahtjev za izvršenje uputiti žalbenom upravnom sudu.

Osnovno je pravilo da sud koji je donio odluku treba osigurati i praćenje provedbe izvršenja, određujući odgovarajuće mjere i rok za izvršenje, osim u dvama slučajevima. U prvom slučaju, ako je sudska odluka koja nije izvršena predmet žalbe, stranka će zahtjev za izvršenje uputiti žalbenom upravnom sudu koji će o tom zahtjevu i odlučiti. U drugom slučaju, temeljenom na članku L 911-4, stavak 5. Zakonika o upravnom sudovanju, upravni sud i žalbeni upravni sud mogu zahtjev o izvršenju zbog osobitih poteškoća proslijediti na rješavanje Državnom savjetu. ${ }^{53}$ Postupak izvršenja pokrenut na temelju zahtjeva stranke možemo podijeliti u dvije faze, prvu, tzv. sporazumnu, "nesudsku", u kojoj predsjednik suda pred kojim je pokrenut postupak izvršenja ili sudac izvjestitelj kojeg je on odredio imaju mogućnost poduzeti određene radnje kako bi osigurali izvršenje upravnosudske odluke koja je predmet zahtjeva. U slučaju da prva faza ne dovede do izvršenja upravnosudske odluke, može se pokrenuti rješavanje sudskim putem koje rezultira donošenjem određenih prisilnih mjera. ${ }^{54}$

\subsection{Načelo odbijanja naloga protiv uprave u sudskoj praksi}

Može li autoritet pravomoćnosti dovesti do upravnosudske ovlasti izdavanja naloga u slučaju trajnog neizvršenja upravnosudskog rješenja koje se bez ikakve poteškoće može izvršiti? Odgovor je svakako pozitivan u odnosu na fizičke osobe. Tako, primjerice, protiv pojedinaca koji bespravno zauzimaju javno dobro, uključujući i u postupku za privremenu pravnu zaštitu. Treba također

2 Gjidara, op. cit. u bilj. 15, str. 100.

53 "Upravni sud ili žalbeni upravni sud mogu uputiti zahtjev za izvršenje Državnom savjetu."

54 Vidi u: Malenica, op. cit. u bilj. 10, str. 30 - 31. 
spomenuti pretpostavku utemeljenu na sudskoj praksi Prefet de l'Eure iz 1913. o nedopuštenosti zahtjeva koji uprava upućuje upravnom sudu kada javnopravna tijela sama mogu donijeti potrebne odluke.

Međutim, odgovor je posve suprotan u slučaju nalogâ koje upravni sud izriče protiv same uprave. Naime, sukladno ustaljenoj sudskoj praksi, smatra se da upravni sudac ne treba upućivati naloge upravi tako da se zahtjevi u svrhu nalaganja smatraju nedopuštenima prema načelu javnog poretka. ${ }^{55}$

Ovo rješenje se najčešće objašnjava, a ponekad i opravdava, diobom vlasti, zbog navodnog razloga da bi nalaganje upravi bilo upravljanje, dok u stvarnosti upravni sudac izriče ili, prema potrebi, posebno svečano ponavlja upravi, da treba izvršiti, što bolje ili što prije, njegovu inicijalnu odluku zbog toga što je postala pravomoćna. ${ }^{56}$

\section{POSTUPAK PRISILNOG IZVRŠENJA PRED UPRAVNIM I ŽALBENIM UPRAVNIM SUDOM}

Postupak izvršenja se na temelju zahtjeva može pokrenuti pred upravnim sudom, žalbenim upravnim sudom te Državnim savjetom, ovisno o tome koji je sud donio odluku čije se izvršenje zahtijeva.

Kada stranka podnese upravnom ili žalbenom upravnom sudu zahtjev za izvršenjem, zakonodavac predviđa dva načina za rješavanje zahtjeva za izvršenje. Prvi "sporazumni" način odnosi se na situacije kada predsjednik upravnog suda odnosno predsjednik žalbenog upravnog suda ili sudac izvjestitelj kojeg je ovlastio predsjednik suda donose sve potrebne mjere kako bi se upravnosudska odluka na koju se zahtjev odnosi izvršila. Ako predsjednik upravnog suda odnosno predsjednik žalbenog upravnog suda, postupajući po zahtjevu, smatra da je javnopravno tijelo izvršilo odluku, ili da je zahtjev za izvršenjem neosnovan, dolazi do obustave postupka.

Prema članku R 921-1 Zakonika o upravnom sudovanju zahtjev za izvršenje upravni sud će uzeti u razmatranje tek po isteku roka od tri mjeseca od dostave odluke na čije se izvršenje zahtjev odnosi. U slučaju izričitog odbijanja izvršenja odluke od strane javnopravnog tijela, rok od tri mjeseca ne ograničava sud u donošenju naloga o izvršenju. Isto tako, ako je odlukom koja nije izvršena

55 Vidi sudsku praksu Državnog savjeta na https://www.conseil-etat.fr/ressources/ avis-aux-pouvoirs-publics/consiliaweb (15. rujna 2020.).

56 Gohin, op. cit. u bilj. 41, str. 391. 
određena neka hitna mjera, zahtjev se može uzeti u razmatranje odmah nakon dostave odluke. ${ }^{57}$

Ako "sporazumni" način ne uspije, može se pokrenuti upravnosudski postupak u kojem predsjednik upravnog suda i žalbenog upravnog suda donosi odluku o nastavku postupka koji će rezultirati donošenjem određenih prisilnih mjera za izvršenje. On će to učiniti kada stranka koja podnese zahtjev traži pokretanje postupka u roku od mjesec dana nakon dostave rješenja o obustavi postupka. Isto tako, postupak se nastavlja kada je predsjednik donio rješenje o nastavku postupka zato što javnopravno tijelo nije u roku od šest mjeseci izvršilo odluku, protiv kojeg nije moguće uložiti žalbu. ${ }^{58}$ Važno je naglasiti kako na kraju svake godine predsjednici svih upravnih sudova i žalbenih upravnih sudova izvještavaju predsjednika Odjela za izvješća i studije o poteškoćama u izvršenju u sklopu svih postupaka koji su pred tim sudovima pokrenuti. Prema potrebi, ti se podaci navode u Godišnjem izvješću Državnog savjeta. ${ }^{59}$

\section{POSTUPAK IZVRŠENJA PRED DRŽAVNIM SAVJETOM}

Državni je savjet odgovoran za izvršenje svojih odluka, ali i odluka koje donose specijalizirani upravni sudovi. Također, pred njim se mogu pokrenuti postupci izvršenja a posteriori, nakon što mu upravni sudovi ili žalbeni upravni sudovi proslijede predmet na rješavanje. Unutar Državnog savjeta Odjel za izvješća i studije zadužen je za poduzimanje svih mjera u cilju izvršenja upravnosudskih odluka.

Zahtjev za izvršenje zainteresirane stranke mogu podnijeti Odjelu za izvješća i studije Državnog savjeta u roku od tri ili šest mjeseci, ovisno o tome traži li zainteresirana stranka u zahtjevu samo pomoć pri izvršenju ili uz tu pomoć traži i izricanje periodičke novčane kazne za javnopravno tijelo koje nije izvršilo upravnosudsku odluku. Zahtjev za izvršenje (bez prijedloga periodičke novčane kazne) podnosi se nakon isteka roka od tri mjeseca od dostave upravnosudske odluke koja je ostala neizvršena. Vremensko ograničenje od tri mjeseca ne odnosi se na upravnosudske odluke koje javnopravno tijelo izričito odbija izvršiti ili kada je upravnosudskom odlukom utvrđeno poduzimanje određenih hitnih mjera. U

57 Prema čl. L 911-4 st. 3. Zakonika o upravnom sudovanju, upravni sud i žalbeni upravni sud mogu u slučaju posebnih poteškoća dostaviti predmet na rješavanje Državnom savjetu.

R 921-6 Zakonika o upravnom sudovanju.

59 R 921-8 Zakonika o upravnom sudovanju. Vidi o tome i Malenica, op. cit. u bilj. 10, str. 32 . 
tim slučajevima zainteresirana stranka ima mogućnost odmah nakon dostave upravnosudske odluke zatražiti izvršenje podnoseći zahtjev za izvršenje. Isto tako, postupak izvršenja pred Državnim savjetom moguće je pokrenuti tek nakon proteka roka za izvršenje ako je taj rok bio određen u upravnosudskoj odluci.

Nakon zaprimanja zahtjeva sudac izvjestitelj kojeg je odredio predsjednik Državnog savjeta poduzima sve potrebne radnje kako bi u tom "sporazumnom" nesudskom postupku osigurao izvršenje upravnosudske odluke na koju se odnosi zahtjev. Sudac izvjestitelj ima mogućnost zatražiti savjet i od Odbora (suženog tijela Državnog savjeta) koji čine predsjednik i zamjenik predsjednika Odjela za izvješća i studije, sam sudac izvjestitelj te tri člana Državnog savjeta, među kojima je i predsjednik Odjela za sporove. ${ }^{60}$

Zahtjev za izvršenje kojim sama stranka predlaže određivanje periodičke novčane kazne može se podnijeti Državnom savjetu samo nakon isteka roka od šest mjeseci od dostave upravnosudske odluke. ${ }^{61}$ Zahtjev odnosno predmet najprije se obrađuju u Odjelu za izvješća i studije u tzv. sporazumnom nesudskom postupku u kojem sudac izvjestitelj može poduzeti radnje kako bi osigurao izvršenje upravnosudske odluke koja je predmet zahtjeva za izvršenje. Nakon preispitivanja predmeta predsjednik Odjela za izvješća i studije dostavlja bilješku predsjedniku Odjela za sporove koja se zajedno s dokumentima koji su u prilogu dodaje u spis predmeta i predaje sudskom vijeću. ${ }^{62}$ Predsjednik Odjela za sporove donosi rješenje o početku sudskog postupka koje su upisuje u tajništvo Odjela za sporove te se dostavlja strankama kako bi se izveli dokazi i hitno riješio predmet.

Osim naloga i periodičke novčane kazne Zakonik o upravnom sudovanju dodatno propisuje i druga dva sustava koji mogu djelovati odvojeno ili kumulativno. ${ }^{63}$ Riječ je o mogućnosti reguliranoj u Monetarnom i financijskom zakonu, prema kojem se javnopravno tijelo može prisiliti na plaćanje novčane kazne koja je utvrđena upravnosudskom odlukom. ${ }^{64}$ Osim institucionalnog kažnjavanja,

60 R 931-2 Zakonika o upravnom sudovanju.

${ }_{61}$ R 931-3 Zakonika o upravnom sudovanju.

62 R 931-6 Zakonika o upravnom sudovanju.

63 Chapus, op. cit. u bilj. 30, str. 1136.

${ }_{64}$ Čl. L 911-10 i čl. L 312-12, Code monétaire et financier, https://www.legifrance. gouv.fr/affichCode.do?cidTexte=LEGITEXT000006072026 (2. listopada 2019.). 
Zakonik o upravnom sudovanju u članku R 921-765 i R 931-866 predviđa mogućnost kažnjavanja i fizičke osobe koja unutar javnopravnog tijela nije poduzela potrebne radnje za izvršenje pravomoćnih upravnosudskih odluka. ${ }^{67}$

\section{POSTUPAK PRISILNE NAPLATE DOSUĐENE NOVČANE KAZNE}

Zakonom od 16. srpnja 1980. o izvršenju presuda protiv javnopravnih tijela uspostavljen je sustav prisilne naplate s ciljem automatskog izvršenja novčanih kazni koje se izriču protiv uprave.

Ovaj osobito složen mehanizam preuzima se člankom L 911-9 Zakonika o upravnom sudovanju. Osim toga, iz članka 17. Zakona o pravima građana u njihovim odnosima s upravom (DCRA) od 12. travnja 2000. proizlazi da se odredba članka 1. iz Zakona od 16. srpnja 1980. primjenjuje na odluke suca u postupcima privremene pravne zaštite kojima se određuje naplata potraživanja.

Prema tom mehanizmu iz članka L 911-9 Zakonika o upravnom sudovanju, prisilna naplata odnosi se izravno na državu i na decentralizirana tijela javne vlasti: tijela lokalne i područne samouprave i javne ustanove neizravno, putem nadzornog tijela, uz sve detalje kojima se nastoji spriječiti ili zaobići, odnosno sankcionirati neizvršenje upravnosudske odluke.

Kada je upravnosudskom odlukom koja je postala pravomoćna određen iznos koji javnopravno tijelo treba platiti, tada za taj iznos treba izdati nalog za plaćanje u roku od dva mjeseca od dostave odluke ako postoje raspoloživa sredstva. ${ }^{68}$ Ovaj rok može se eventualno produžiti na četiri mjeseca ako javnopravno tijelo nema dovoljno financijskih sredstava za podmirenje dosuđene kazne. Takav postupak prisilne naplate razlikuje se ovisno o tome odnosi li se na državu, tijela lokalne samouprave ili javne ustanove. ${ }^{69}$

Kada je presudom državi određena novčana kazna, nakon isteka zakonom propisanog roka u kojem je ona dužna provesti plaćanje, stranka na koju se

65 "U slučaju potpunog ili djelomičnog neizvršenja ili zakašnjelog izvršenja sud će prebrojiti zateznicu koju je izrekao. Sud ne može izmijeniti visinu konačne zateznice tijekom prebrojavanja, osim ako neizvršenje odluke proizlazi iz slučaja događaja ili više sile. Sud može unajmiti ili ukinuti privremenu zateznicu, čak i ako se utvrdi neizvršenje."

66 "Sud može odlučiti da dio zateznice neće biti isplaćen podnositelju zahtjeva. Neisplaćeni dio namijenjen je državnom proračunu."

67 Vidi o tome Malenica, op. cit. u bilj. 10, str. 33 - 34.

68 L 911-9 Zakonika o upravnom sudovanju.

69 Gjidara, op. cit. u bilj. 15, str. 105. 
odnosi presuda može od računovodstva, dostavljajući mu i primjerak presude, zatražiti plaćanje iznosa koji je sudac odredio. ${ }^{70}$

Kada je sudskom odlukom lokalnoj samoupravi ili javnoj ustanovi utvrđena obveza plaćanja konkretnog novčanog iznosa, obvezni su to učiniti u roku od dva mjeseca od dostave odluke. U slučaju da javnopravno tijelo u zakonom predviđenom roku ne izvrši plaćanje, postupak preuzima tijelo koje nad njim obavlja nadzor ili predstavnik države. ${ }^{71}$ Oni imaju ovlast opomenuti "neposlušno" tijelo lokalne samouprave odnosno javnu ustanovu da osigura potrebna sredstva za plaćanje svoje sudskom odlukom utvrđene obveze. Ako tijelo lokalne samouprave ili javna ustanova ne raspolažu s dovoljno sredstava, državni će predstavnik odnosno nadležno tijelo poslati opomenu kojom poziva da se trebaju osigurati potrebna financijska sredstva za plaćanje ${ }^{72}$, a ako se ni nakon opomene ne osiguraju sredstva, tada je nadzorno tijelo odnosno državni predstavnik zakonom ovlašteno da to podmiri. Oni mogu iskoristiti prvotno namijenjena novčana sredstva, a dodatne izdatke mogu namiriti povećanjem lokalnih poreza ili pak donijeti odluku o prodaji određene imovine koja pripada tijelu lokalne samouprave ili javnoj ustanovi, pod pretpostavkom da nije riječ o imovini koja je nužna za kontinuirano i ispravno funkcioniranje javnih službi. ${ }^{73}$

Ako bi i nadzorno tijelo propustilo ispuniti svoju obvezu plaćanja umjesto lokalne samouprave ili javne ustanove, a imalo je za to dovoljno sredstava, počinilo je pogrešku jer nije djelovalo unatoč postojanju formalnog zahtjeva za njegovo djelovanje. Tada je riječ o odgovornosti države koja zamjenjuje "neposlušno" javnopravno tijelo. ${ }^{74}$

\section{ODGOVORNOST JAVNIH SLUŽBENIKA ZA NEIZVRŠENJE UPRAVNOSUDSKE ODLUKE}

Zakonom od 16. srpnja 1980. godine propisano je da se službeniku javnopravnog tijela koji nije izvršio nalog za plaćanje iznosa koji je dosuđen javnopravnom

70 L 911-9 st. 1. Zakonika o upravnom sudovanju.

71 L 911-9 st. 2. Zakonika o upravnom sudovanju.

72 Nakon opomene čelnik lokalne samouprave odnosno javne ustanove dužan je u roku dva mjeseca od dostave opomene donijeti nalog za plaćanje. Ako nalog za plaćanje nije donesen u tom razdoblju, državni predstavnik će u roku mjesec dana poslati lokalnoj samoupravi ili javnoj ustanovi službenu obavijest o plaćanju iznosa po službenoj dužnosti (R 911-9 st. 4.).

73 Državni savjet, presuda u predmetu Société fermière de Campoloro od 18. studenog 2005., preuzeto iz: Gjidara, op. cit. u bilj. 15, str. 106.

74 Ibid., str. 106. Vidi u: Malenica, op. cit. u bilj. 10, str. $34-35$. 
tijelu, odnosno čije postupanje je dovelo do izricanja periodičke novčane kazne protiv javnopravnog tijela čiji je on zaposlenik, može izreći novčana kazna (les peines d'amendes). Riječ je, dakle, o sustavu profesionalne odgovornosti službenika do koje je došlo njegovim činjenjem odnosno propuštanjem. Tijelo nadležno za izricanje novčane kazne jest Sud za proračunsku i financijsku disciplinu kojemu je stranka uputila zahtjev kada nije podmirena obveza. Razlikujemo kaznu koja je službeniku izrečena zbog neizvršenja naloga za plaćanje novčane kazne te kaznu za neizvršenje koje je dovelo do izricanja periodičke novčane kazne javnopravnom tijelu. U prvom slučaju postupak protiv osobe odgovorne za neizvršenje upravnosudske odluke kojom je određena novčana kazna može se pokrenuti na inicijativu stranke na koju se upravnosudska oduka odnosi ili na temelju postupka koji pokreću tijela ovlaštena statutom Suda. ${ }^{75} \mathrm{U}$ drugom slučaju imamo javne službenike čije je postupanje dovelo do toga da je javnopravnom tijelu dosuđena periodička novčana kazna zbog neizvršenja pravomoćne upravnosudske odluke. Prilikom određivanja iznosa periodičke novčane kazne otpravak odluke kojom se izriče periodička novčana kazna i odluka o iznosu novčane kazne dostavljaju se državnom odvjetništvu pri Sudu za proračunsku i financijsku disciplinu. ${ }^{76}$

Zakonom o financijskim sudovima propisano je da se javni službenik može kazniti kaznom od najmanje 300 eura, ovisno o iznosu godišnje bruto plaće koju osoba ima na dan kada je trebalo izvršiti upravnosudsku odluku. ${ }^{77}$

\section{NOVČANA KAZNA KAO POTPORA UPRAVNOSUDSKOM NALOGU}

Naime, novi postupak izricanja novčane kazne kao potpore upravnosudskom nalogu proizlazi iz reforme koja je provedena Zakonom od 8. veljače 1995. pred upravnim i pred žalbenim upravnim sudovima te pred Državnim savjetom time što se to izravno odnosi na te sudove, na temelju načela iz prethodno navedenih članaka L 911-1 i L 911-2 Zakonika o upravnom sudovanju. Kada se koristi u upravnom sporu o zakonitosti, novčana kazna također omogućuje upravnom sucu da ide dalje od samog poništenja spornog upravnog akta zbog pravnih razloga.

75 L 911-10 Zakonika o upravnom sudovanju.

76 R 921-7 i R 931-8 Zakonika o upravnom sudovanju.

77 Čl. L 317-7 i čl. 312 Code des juridictions financières, https://www.legifrance.gouv. fr/affichCode.do?cidTexte=LEGITEXT000006070249 (3. listopada 2019.). Vidi u: Malenica, op. cit. u bilj. 10, str. 35 - 36 . 
Riječ je o ishođenju mjere potrebne za izvršenje:

- odluke kojom se meritorno rješava spor u određenom smislu (Državni savjet provjerava je li ispunjena potrebna izvršna mjera u tom slučaju)

- nove odluke nakon izvođenja dokaza, a u određenom roku. ${ }^{78}$

Naime, revizija spisa građanina koja se zahtijeva putem upravnosudskog naloga za upravu predstavlja obvezu koja se sankcionira samo kombinacijom naloga i novčane kazne kako bi se osigurala učinkovitost cjelovitog sustava. Na primjer, presudom upravnog suda iz Rennesa od 28. rujna 1995., kojom se poništavaju odluke rektora Sveučilišta Rennes-II koji odbija upisati studente prve godine Više škole za tjelesni odgoj i sport, nalaže se rektoru da studente upiše u roku od osam dana od dostave presude, pod prijetnjom novčane kazne od 500 tadašnjih francuskih franaka po danu zakašnjenja.

Međutim, kombinacija tih dvaju postupaka pretpostavlja da se poštuju pravila o preraspodjeli nadležnosti između sudova opće nadležnosti i upravnih sudova. ${ }^{79}$

\subsection{Zajednički dijelovi u dva postupka izricanja novčane kazne}

Novčana kazna jedna je od mjera potrebnih za izvršenje ili konačne presude upravnog suda pred tim sudom ili presude upravnog suda koji se nalazi u nadležnosti žalbenog suda pred kojim je podnesena žalba žalbenom upravnom sudu odnosno presude žalbenog upravnog suda.

Mehanizam koji je na snazi nije posebno naklonjen stranci u postupku u traženju opće ravnoteže sporne situacije koja se može razumjeti, a zbog razmatranja od općeg interesa. To se provjerava kroz tri zahtjeva.

Prvo, zahtjev koji se odnosi na to da niži sud odredi izvršnu mjeru za takvu upravnosudsku odluku, a u slučaju potrebe, tim zahtjevima dodaje novčanu kaznu. Ne može se podnijeti, osim izričite odluke o odbijanju izvršenja koju je istaknulo javnopravno tijelo, prije nego što je istekao rok od tri mjeseca počevši od dostave konkretne odluke. Međutim, kada je riječ o odlukama kojima se nalaže hitna mjera, tada se zahtjev može podnijeti bez odgode.

Drugo, u slučaju u kojemu sud raspolaže, u presudi čije se izvršenje zahtijeva, određenim rokom u kojemu uprava treba donijeti izvršne mjere koje je sud propisao, zahtjev se može podnijeti tek nakon isteka tog roka.

78 Gohin, op. cit. u bilj. 41, str. 403.

79 Ibid., str. 404. 
Treće, "u slučaju odbacivanja prigovora koji se upućuje upravnom tijelu, kako bi se postiglo izvršenje odluke upravnog suda ili žalbenog upravnog suda, samo jednom izričitom odlukom počinju teći rokovi za podnošenje tužbe". Primijetit ćemo da ovaj posljednji zahtjev, povoljan za građanina, definira rok za podnošenje tužbe samo u izričitoj odluci o odbacivanju. ${ }^{80}$ Zakonik dodaje da "kada se izriče novčana kazna, sudsko vijeće određuje datum stupanja na snagu”. U načelu, novčana je kazna privremena, osim kada je konačna, kao što proizlazi iz članka L 91 1-6 Zakonika o upravnom sudovanju koji glasi:

"Novčana kazna je privremena ili konačna. Kaznu se smatra privremenom osim ako sud nije odredio njezinu konačnost. Ona je neovisna o određenoj naknadi štete i pripadajućim kamatama."

Treba napomenuti da se pred Državnim savjetom zahtjevi za izricanjem novčane kazne ne moraju podnijeti preko odvjetnika pri Državnom savjetu i podliježu pojednostavljenoj istrazi i hitnosti.

K tome, članak L 911-7, 1. stavak Zakonika o upravnom sudovanju precizira da:

"U slučaju potpunog ili djelomičnog neizvršenja ili zakašnjelog izvršenja, sud će preračunati zateznicu koju je izrekao".

I konačno, članak L 911-8 Zakonika dodaje kako iz razloga koji se odnose na pravičnost i opći interes, a kako bi se izbjeglo bezrazložno bogaćenje u upravnom sporu, da:

"Sud može odlučiti da dio zateznice neće biti isplaćen podnositelju zahtjeva. Neisplaćen dio namijenjen je državnom proračunu”.

Prethodno spomenuti članak R 921-7 Zakonika o upravnom sudovanju propisuje da:

"Kada na dan stupanja na snagu novčane kazne, koju je izrekao upravni sud ili žalbeni upravni sud, taj sud po službenoj dužnosti ili zbog toga što mu je zainteresirana stranka uputila zahtjev, utvrdi da izvršne mjere koje je on propisao nisu poduzete, sud započinje s određivanjem iznosa novčane kazne" (l. stavak). „U tom slučaju preslika presude kojom se izriče novčana kazna i odluka u kojoj se određuje iznos novčane kazne dostavlja se državnom odvjetništvu pri Sudu za proračunsku i financijsku disciplinu" (2. stavak).

Također, sukladno članku R 921-8 Zakonika navodi:

"Na kraju svake godine predsjednici svih upravnih sudova i predsjednici svih žalbenih upravnih sudova predaju izvješće predsjedniku Odjela za izvješća i studije Državnog savjeta o poteškoćama u izvršenju koje su im podnesene.

$80 \quad$ Ibid., str. 404. 
Ako je potrebno, godišnje izvješće Državnog savjeta sadržava i napomenu o tim poteškoćama”.

\subsection{Vrlo ograničena praksa dvaju postupaka izricanja novčane kazne}

Sljedećom tablicom sažet ćemo zakonsku osnovu upravnosudskog djelovanja u izvršenju odluka upravnih sudova ${ }^{81}$ :

\begin{tabular}{|l|l|l|}
\hline $\begin{array}{l}\text { Upravnosudski nalog } \\
\text { zbog neizvršenja } \\
\text { pravomoćne presude } \\
\text { (Zakon od 8. veljače 1995.) }\end{array}$ & $\begin{array}{l}\text { Zadržano izricanje novčane } \\
\text { kazne: pomoć pri izvršenju } \\
\text { upravnosudske odluke } \\
\text { (Zakon od 16. srpnja 1980.) }\end{array}$ & $\begin{array}{l}\text { Novo izricanje novčane } \\
\text { kazne: podrška pri } \\
\text { upravnosudskom nalogu } \\
\text { (Zakon od 8. veljače 1995.) }\end{array}$ \\
\cline { 1 - 2 } $\begin{array}{l}\text { U određenom smislu: } \\
\text { čl. L 911-1 }\end{array}$ & $\begin{array}{l}\text { "prijateljskim putem" } \\
\text { (Državni savjet: R 931-2; } \\
\text { niži sudovi: R 921-5) }\end{array}$ & \\
\cline { 1 - 2 } $\begin{array}{l}\text { U određenom roku: } \\
\text { čl. L 911-2 }\end{array}$ & $\begin{array}{l}\text { upravnosudskim putem } \\
\text { (Državni savjet: L 911-5 i } \\
\text { R 931-3; niži sudovi: } \\
\text { L 911-4 i R 921-6) }\end{array}$ & \\
\hline
\end{tabular}

Na temelju brojki objavljenih u Javnom izvješću Državnog savjeta zaključujemo da su opći upravni sudovi zabilježili 2017 zahtjeva za pomoć pri izvršenju tijekom 2010. godine na 10914 riješenih predmeta, ali ne možemo odrediti koliko ih je zatraženo u upravnoj fazi, odnosno koliko ih je riješeno mirnim odnosno upravnosudskim putem, koji je dakako u manjini, odnosno tek 331 . O trenutačnoj ulozi upravnog sudovanja u izvršenju vlastitih odluka, a bez dostupnih statističkih podataka o nalogu, ne možemo imati dovoljno jasnu viziju o izvršenju odluka upravnih sudova, osim ako ne uzmemo u obzir ovaj mirni način rješavanja kojim se korisno i učinkovito nastoji izbjeći primjena upravnosudskog izricanja novčane kazne u onom dijelu u kojem je prijetnja tom obvezom jednako korisna kao i sama primjena.

Međutim, ako se držimo samo upravnosudskog puta s namjerom izricanja novčane kazne, treba ustvrditi da meritorna sudska praksa Visoke skupštine ostaje vrlo nepovjerljiva. Prije svega, primijetit ćemo da je do prve pozitivne primjene Zakona od 16. srpnja 1980. došlo tek 1985., Odjel za sporove konačno je prihvatio dosuditi novčanu kaznu posebno neposlušnoj općini zbog dugotrajnog neizvršenja pravomoćne presude.

81 Vidi o tome ibid., str. 406. 
Osim toga, u trenutačnom stanju upravnog spora izricanje novčane kazne upravnosudskim putem odbacit će se u sljedećim slučajevima:

- ako je izvršenje postalo nemoguće u materijalnom ili pravnom smislu za upravu

- ako je sigurno da će neizvršenu prvostupanjsku presudu poništiti žalbeni sudac

- ako je stranka u identičnom predmetu već ishodila izricanje novčane kazne u svoju korist

- ako se izvršenje upravnosudske odluke od uprave može postići nekim drugim sredstvima

- ako uprava zahtijeva dodatni rok, obično od dva mjeseca, jer smatra da je izvršenje u tijeku ili jednostavno vodeći računa o okolnostima u predmetu. $^{82}$

Od tada su rezultati upravnosudskog puta za izricanje novčane kazne pred Državnim savjetom postali razočaravajući zato što su bili slabi. Također, u pogledu izvršenja odluka upravnih sudova, broj postupaka u kojima se izriče novčana kazna, nakon oduzimanja spisa u kojima se određuju iznosi novčanih kazni, tijekom 2007. bilo ih je samo trideset sedam, što je predstavljalo samo $21 \%$ svih riješenih predmeta te godine.

Ipak, čak i u ovako restriktivnim uvjetima primjene i, kao što se najviše od svega bojao, Državni savjet se već mogao izložiti riziku i vidjeti da nakon upravnosudskog puta nije odmah uslijedilo zahtijevano izvršenje. To se osobito dogodilo u slučaju tzv. afere Tennis Jean Becker iz 1988. Odjel za sporove Državnog savjeta tada je uspio u postupku u pogledu iznosa novčane kazne zbog neizvršenja, što neposlušna lokalna uprava ubrzo nije mogla tolerirati. Svake godine Javno izvješće Državnog savjeta navodi najizraženije poteškoće pri izvršenju u okviru svojih "posebnih komentara koji se odnose na točno određene predmete". Kao što je to bio slučaj između listopada 2009. i siječnja 2011. kada je bila riječ o predmetima koji su se odnosili na poništenje dozvola za korištenje radiofonijskih usluga elektromagnetskim putem ili o pravilima koja se odnose na isplatu zateznih kamata ili o tome da treba ograničiti pretjerani broj zahtjeva za izvršenje uz izricanje novčanih kazni. No, istina je da to javno prokazivanje nije zanimljivo ni učinkovito kada na nejasan način i u par riječi, u tradiciji bezlične javne službe, nastoji ne dopustiti identificiranje odgovornih za tako ozbiljno nepoštovanje autoriteta pravomoćnosti, pa prema tome i upravne zakonitosti i u konačnici pravne države. ${ }^{83}$

82 Ibid., str. $406-407$.

83 Ibid., str. 407. 


\section{ODGODA IZVRŠENJA UPRAVNOSUDSKIH ODLUKA}

Zahtjev za odgodu je dodatak tužbi za poništenje (u žalbenom ili kasacijskom postupku) ili u reformacijskom postupku (u žalbenom postupku) upravnosudske odluke donesene u prvom stupnju (žalba) ili u zadnjem stupnju (kasacija). Nadležni žalbeni sud za određivanje odgode izvršenja upravnosudske odluke iz prvog stupnja, osim iznimki predviđenih u postupcima za privremenu pravnu zaštitu, sastoji se od sudskih vijeća žalbenih upravnih sudova. Nadležni kasacijski sud za određivanje odgode izvršenja upravnosudske odluke u zadnjem stupnju sastoji se od sudskog vijeća Državnog savjeta. ${ }^{84}$

Zajednički postupovni uvjeti primjenjuju se na ove režime odgode izvršenja upravnosudske odluke upravnih sudova ili žalbenih upravnih sudova.

Zamjenom postupka odgode izvršenja upravnih odluka hitnim zahtjevom za obustavom prekinula se paralelnost koja je prethodno postojala između odgode izvršenja upravnih ili upravnosudskih odluka, dok su u oba ova slučaja materijalni uvjeti za odgodu izvršenja bili potpuno isti na temelju sudske prakse Državnog savjeta u onom dijelu koji se odnosi na odgodu izvršenja upravnih odluka i za zakonske tekstove u onom dijelu koji se odnosi na odgodu izvršenja upravnosudskih odluka.

Postojala su dva materijalna uvjeta odgode izvršenja:

1. rizik da će izvršenje pobijane odluke dovesti do teško popravljivih posljedica

2. postojanje barem jednog razloga u zahtjevu koji se pojavljuje tijekom izvođenja dokaza, koji je ozbiljan i može opravdati poništenje pobijane odluke..$^{85}$

Upravo je ta konstrukcija, koja se sada primjenjuje samo na upravnosudske odluke, preuzeta u članku R 811-17 Zakonika o upravnom sudovanju za određivanje odgode izvršenja presuda upravnih sudova pred žalbenim upravnim sudovima, prema sljedećem načelnom mehanizmu: “...odgodu izvršenja presude može zatražiti podnositelj zahtjeva ako bi izvršenje prvostupanjske odluke moglo prouzročiti teško popravljive posljedice i ako argumenti zahtjeva izgledaju ozbiljni u određenoj fazi ispitnog postupka."

$84 \quad$ Ibid., str. $392-397$.

85 Ibid. 


\subsection{Posebni režimi odgode izvršenja}

Posebni režimi odgode izvršenja su, u načelu, oni koji se primjenjuju samo na odluke koje donosi žalbeni upravni sud i odgovaraju dvjema različitim pretpostavkama:

Prva pretpostavka posebnog režima, predviđena člankom R 811-15 Zakonika o upravnom sudovanju, odnosi se na odgodu izvršenja presuda upravnih sudova koji su poništili upravnu odluku, uglavnom zbog nezakonitosti (prekoračenje ovlasti). ${ }^{86}$

Druga pretpostavka proizlazi iz članka R 811-16 Zakonika, odnosi se na odgodu izvršenja presuda upravnih sudova donesenih u sporu pune jurisdikcije. Naime, u predmetnom članku navodi se: "Kad žalbu podnosi osoba koja nije podnositelj zahtjeva u prvom stupnju, sud može na zahtjev žalitelja sukladno odredbama članaka R 533-2 i R 541-6 narediti odgodu izvršenja pobijane presude ako bi njezino izvršenje za podnositelja žalbe značilo trajni gubitak iznosa koji on ne bi snosio u slučaju da sud prihvati njegove argumente u žalbenom postupku."

Ovaj mehanizam vrijedi za žalbu u žalbenom postupku kao i iznimno za žalbu u kasacijskom postupku. Međutim, primijetit ćemo da u ovom slučaju, tijekom izvođenja dokaza, ozbiljan razlog treba opravdavati, ne samo poništenje naloga za naplatu potraživanja, već i odbijanje zahtjeva za naplatom potraživanja.

\subsection{Postupovni uvjeti koji su zajednički režimima za odgodu izvršenja}

Postupovni uvjeti koji su zajednički svim režimima odgode izvršenja upravnosudskih odluka u načelu su uvjeti općeg prava za pokretanje postupka u prvom stupnju, kako pred žalbenim sucem za odgodu izvršenja upravnosudske odluke upravnih sudova, tako i pred kasacijskim sucem za odgodu izvršenja upravnosudske odluke žalbenih upravnih sudova. ${ }^{87}$

Ipak, Zakonik o upravnom sudovanju dodatno navodi tri sljedeće točke:

Članak R 811-17-1 Zakonika o upravnom sudovanju kaže da pred žalbenim upravnim sudom: "Pod prijetnjom nedopuštenosti, u skladu s odredbama članaka R 811-15 do R 811-17, zahtjevi za odgodom izvršenja pobijane prvostupanjske

86 "Ako se žalba odnosi na presudu upravnog suda koja poništava upravni akt, žalbeni sud može na zahtjev podnositelja žalbe narediti da se odgodi izvršenje presude ako argumenti podnositelja žalbe u određenoj fazi ispitnog postupka, osim poništenja ili izmjene pobijane presude, ozbiljno i dokazivo pobijaju zaključke koji su imali za cilj poništenje akta i koje je presuda smatrala valjanim."

87 Gohin, op. cit. u bilj. 41, str. $395-400$. 
odluke predaju se u zahtjevu odvojenom od žalbe u žalbenom postupku u kojem se nalazi preslika te žalbe".

Jednako tako, pred Državnim savjetom, kasacijski sudac, u skladu s primjenom članka R 821-5-1, stavka 2. Zakonika: "Žalbeni upravni sud koji određuje odgodu izvršenja prvostupanjske upravnosudske odluke uvijek može opozvati tu odgodu". Članak R 811-18 Zakonika o upravnom sudovanju u tom smislu propisuje: “...u bilo kojem trenutku žalbeni sud može okončati odgodu koju je odredio". Isto vrijedi i pred Državnim savjetom, kasacijski sudac u skladu s primjenom članka R 821-5, stavak 2. Zakonika propisuje da "u bilo kojem trenutku sudsko vijeće može okončati odgodu koju je bio odredio.” Nadalje, članak R 81 1-19 Zakonika o upravnom sudovanju propisuje da u slučaju primjene članaka R 811-14 do R 811-18, tj. u svim režimima odgode izvršenja presuda upravnih sudova, protiv presuda žalbenih upravnih sudova "mogu se uložiti žalbe u kasacijskom postupku pred Državnim savjetom u roku od petnaest dana od njihove dostave". ${ }^{88}$

\section{ZAKLJUČAK}

“Nakon postupnoga razvoja izvršenja upravnosudskih odluka koji je ipak bio obilježen važnim napredovanjem u sudskoj praksi, francuski je zakonodavac od 1980. i 1995. "osigurao" upravnom sudovanju najšire ovlasti kako bi javnoj upravi nametnuo obvezu poštivanja sudskih presuda. Naime, puna i učinkovita provedba sudskih odluka, posebno onih koje su na štetu (protiv) javnopravnih tijela, važan je kriterij vladavine prava. Širina procesnih metoda usmjerenih na izbjegavanje neizvršavanja upravnosudskih odluka, uključuje poticajne mehanizme (pedagogiju i uvjeravanje) i nakon toga prvotno prinudne mjere, a ponekad i represivne mjere koje uključuju ne samo financijsku odgovornost javnopravnih tijela nego i osobnu odgovornost službenika koji su odgovorni za neizvršavanje. Premda je to jedna od temeljnih značajka pravne države, stvarno i potpuno izvršenje upravnih presuda, kojima se poništava, između ostalog, konkretne upravne akte, nije uvijek bilo zajamčeno u Republici Francuskoj. Francuski je zakonodavac zbog toga bio primoran izraditi više sustava koje je stavio na raspolaganje stranci (tužitelju) za postizanje konkretnog izvršenja i prisiliti javnu upravu da izvrši te presude, štoviše da sankcionira fizičke osobe koje sprječavaju to izvršenje." ${ }^{89}$

88 Vidi Zakonik o upravnom sudovanju Republike Francuske.

89 Gjidara; Britvić Vetma, op. cit. u bilj. 4, str. 60 - 61 . 
Prilikom izvršenja upravnosudskih odluka stranke u postupku mogu od Odjela za izvješće i studije Državnog savjeta, predsjednika upravnog suda te predsjednika prizivnog suda tražiti pomoć pri izvršenju ako im je sudska odluka nejasna, nedorečena ili je potrebno primijeniti neki pravni propis. Također, stranka ima mogućnost od Branitelja prava tražiti zaštitu svojih prava u postupku izvršenja, no njegove ovlasti su ograničene na izdavanje preporuke o poštovanju prava i sloboda koje obuhvaćaju i pravo na izvršenje pravomoćne presude.

Osim zahtjeva za pomoć pri izvršenju i zahtjeva za zaštitom prava pred Braniteljem prava, Zakonik o upravnom sudovanju u slučaju neizvršenja upravnosudskih odluka stavlja sudu na raspolaganje dvije prinudne mjere. Riječ je o nalogu za izvršenje i periodičkoj novčanoj kazni. One su donesene u prvoj dobrovoljnoj (nesudskoj) fazi izvršenja nakon koje, u slučaju da je presuda i dalje neizvršena, slijedi represivna faza.

Nalog o izvršenju predstavlja mjeru kojom sud na temelju zahtjeva s ciljem izvršenja upravnosudske odluke unaprijed određuje postupanja koje pravomoćna presuda podrazumijeva, dajući stranci prema potrebi i određeni rok u kojem je ona to dužna učiniti te eventualno i prijetnju periodičkom novčanom kaznom u slučaju neizvršenja. Ovaj postupak pokrenut na temelju zahtjeva stranke ne predstavlja novi upravni spor već nastavak upravnog spora koji je rezultirao donošenjem sudske odluke. Osim institucionalnog kažnjavanja, Zakonik o upravnom sudovanju u članku R 921-7 i R 931-8 omogućuje i kažnjavanja fizičke osobe koja unutar javnopravnog tijela nije poduzela potrebne radnje za izvršenje pravomoćnih upravnosudskih odluka.

Razlikujemo izvršenje upravnosudske odluke kojom je određen iznos koji javnopravno tijelo treba platiti te tada u postupku izvršenja za taj iznos treba izdati nalog za plaćanje u roku od dva mjeseca od dostave odluke ako postoje raspoloživa sredstva. U slučaju da javnopravno tijelo u zakonom predviđenom roku ne izvrši plaćanje, postupak preuzima tijelo koje nad njim obavlja nadzor ili predstavnik države. ${ }^{90}$

Zakonik o upravnom sudovanju jasno propisuje da su presude izvršive te je slijedom toga propisan čitav niz procesnih mjera u slučaju neizvršenja sudskih odluka koje se kreću od poticajnih (preventivnih) pa do prinudnih i represivnih mjera. Zahvaljujući takvom pristupu, analiza upravnog sudovanja, kako je ustrojena u Republici Francuskoj, pokazuje da se nudi više različitih rješenja kao odgovor na zahtjev efikasnog izvršenja upravnosudskih odluka. Na taj način, primjenom mjera za izvršenje dolazimo do učinkovitog koncepta izvršenja koji je ugrađen u francuski pravni sustav.

90 Malenica, op. cit. u bilj. 10, str. 279. 


\section{LITERATURA}

Britvić Vetma, B., Kvaliteta odluka upravnih sudova, u: Hrvatsko-francuski upravnopravni dani, Hrestomatija II, Upravno sudovanje: nacionalni iusporedni aspekti, Pravni fakultet Sveučilišta u Splitu, Sveučilište PanthéonAssas, Paris II, Državni savjet Republike Francuske, Split - Paris, 2016., str. 157 - 182.

Britvić Vetma, B., Upravni spor pune jurisdikcije, doktorska disertacija, Pravni fakultet u Splitu, Split, 2011.

Britvić Vetma, B., Upravno sudovanje u Francuskoj - što možemo naučiti, u: Koprić, I. (ur.), Europeizacija upravnog sudovanja u Hrvatskoj, Institut za javnu upravnu, Zagreb, 2014., str. 227 - 241.

Chapus, R., Droit du contentieux administratif, 12ème ed., Montchrestien, Paris, 2006.

Courrèges, A.; Daël, S., Contentieux administratif, P.U.F., Thémis - droit, Paris, 2013.

Gjidara, M.; Britvić Vetma, B., Hrvatsko-francuski upravnopravni pojmovnik s prilozima, drugo, izmijenjeno i dopunjeno izdanje, Pravni fakultet Sveučilišta u Splitu, Sveučilište Panthéon-Assas, Paris II, Split - Paris, 2018.

Gjidara, M., La fonction administrative contentieuse, L.G.D.J., Paris, 1972.

Gjidara, M., Les causes d'inexécution des décisions du juge administratif et leurs remèdes, Zbornik radova Pravnog fakulteta u Splitu, vol. 52, br. 1, 2015., str. 69 - 109.

Gohin, O., Contentieux administratif, 7. izd., LexisNexis, Paris, 2012.

Malenica, I., Izvršenje upravnosudskih odluka u hrvatskom i poredbenom pravu, doktorska disertacija, Pravni fakultet Sveučilišta u Zagrebu, Zagreb, 2020.

Sauvé, J. M., Etat de droit et efficacité, Actualité Juridique de droit administratif (A.J.D.A.), Paris, posebno izdanje srpanj-kolovoz 1999., str. 119 - 135. 
Summary

\section{Bosiljka Britvić Vetma* \\ Ivan Malenica**}

\section{EXECUTION IN FRENCH ADMINISTRATIVE DISPUTE}

Court decisions are mandatory for the party who must execute them. Similarly, the party may seek that the administrative court "order" the public legal entity to execute court judgements within a specific timeframe. In the case of a refusal to execute a decision, the administrative court can punish the public legal entity. To be more specific, in administrative court adjudication, the Republic of France's procedural methods used in the case of non-execution of administrative court decisions range from incentive to repressive measures.

An immense contribution to effective execution of administrative court decisions has been made by two institutions: the Department for Reporting and Studies of the State Council and the Public Ombudsman.

Keywords: execution of administrative court decisions, judicial review, State Council, Public Ombudsman, Code de Justice Administrative

* Bosiljka Britvić Vetma, Ph. D., Associate Professor, Faculty of Law, University of Split, Domovinskog rata 8, 21000 Split, Croatia; bosiljka.britvic@pravst.hr; ORCID ID: orcid.org/0000-0002-3393-5895

** Ivan Malenica, Ph. D., Minister of Justice and Public Administration in the Government of the Republic of Croatia, Ministry of Justice and Public Administration, Ulica grada Vukovara 49, 10000 Zagreb, Croatia; ivan.malenica@mpu.hr;

ORCID ID: orcid.org/0000-0003-4480-0336 